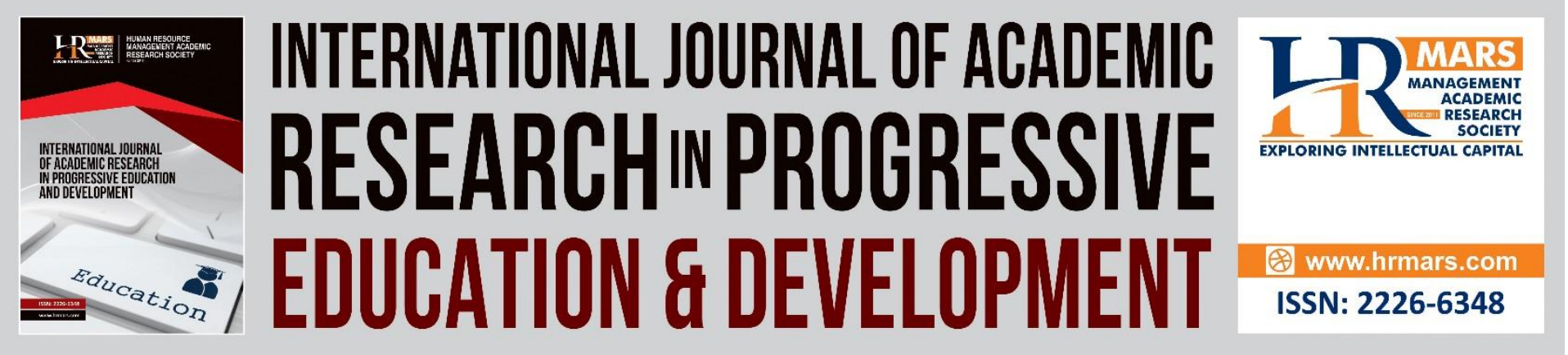

\title{
Attitudes of Students at Al-Ghad International College for Applied Medical Sciences in Saudi Arabia towards Biostatistics
}

\section{Ashraf Mohamed Nemrawi, Nashaat Baioumy}

To Link this Article: http://dx.doi.org/10.6007/IJARPED/v11-i1/11972

DOI:10.6007/IJARPED/v11-i1/11972

Received: 04 November 2021, Revised: 08 November 2021, Accepted: 27 December 2021

Published Online: 20 January 2022

In-Text Citation: (Nemrawi \& Baioumy, 2022)

To Cite this Article: Nemrawi, A. M., \& Baioumy, N. (2022). Attitudes of Students at Al-Ghad International College for Applied Medical Sciences in Saudi Arabia towards Biostatistics. International Journal of Academic Research in Progressive Education and Development, 11(1), 199-215.

Copyright: (C) 2022 The Author(s)

Published by Human Resource Management Academic Research Society (www.hrmars.com)

This article is published under the Creative Commons Attribution (CC BY 4.0) license. Anyone may reproduce, distribute, translate and create derivative works of this article (for both commercial and non-commercial purposes), subject to full attribution to the original publication and authors. The full terms of this license may be seen at: http://creativecommons.org/licences/by/4.0/legalcode

Vol. 11(1) 2022, Pg. 199 - 215

http://hrmars.com/index.php/pages/detail/IJARPED

Full Terms \& Conditions of access and use can be found at http://hrmars.com/index.php/pages/detail/publication-ethics 


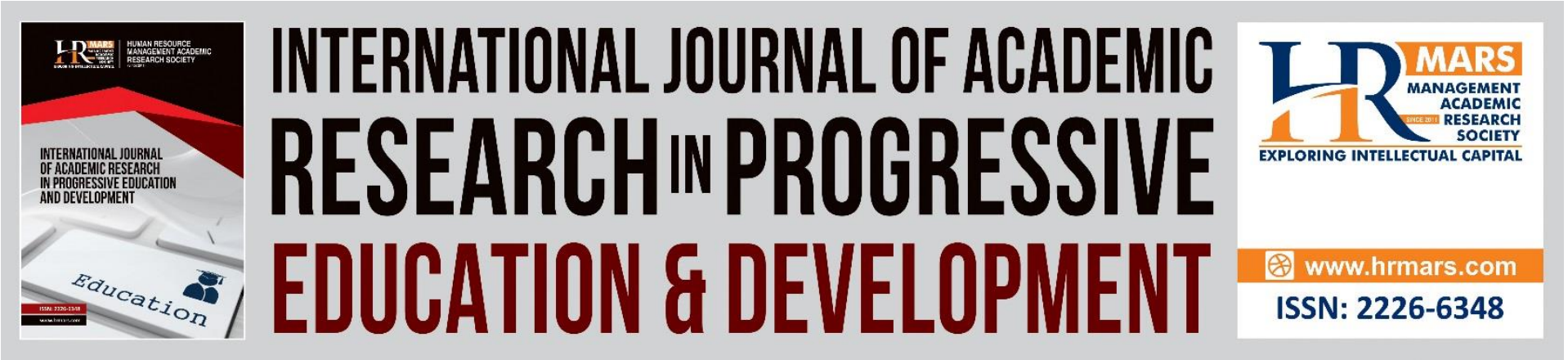

\title{
Attitudes of Students at Al-Ghad International College for Applied Medical Sciences in Saudi Arabia towards Biostatistics
}

\author{
Ashraf Mohamed Nemrawi ${ }^{1}$, Nashaat Baioumy ${ }^{2}$ \\ ${ }^{1}$ Faculty of Islamic Contemporary Studies- Department of Education-University of Sultan \\ Zainal Abidin, 21300, Terengganu, Malaysia, ${ }^{2}$ Faculty of Islamic Contemporary Studies- \\ Department of Education- University of Sultan Zainal Abidin, 21300, Terengganu, Malaysia, \\ Email: ashrafalnemrawi@yahoo.com, nashaatbaioumy@unisza.edu.my
}

\begin{abstract}
The study aimed to showcase the attitudes of students at Al-Ghad International College for Applied Medical Sciences in Saudi Arabia towards biostatistics and developing a valid scale to measure the degree of these attitudes. To that aim, the descriptive analytical approach was used in addition to a 23- paragraph scale developed by the researchers in which validity and reliability were verified. The study gathered survey data from (205) male and female students who were randomly selected from the biostatistics course in the first semester of 2018-2019. The findings of the study mainly showed that the attitudes of students at Al-Ghad International College towards biostatistics was medium, approximately half of the students' had a medium level of attitude, a quarter had a high level of attitude and almost the same had a low level of attitude towards biostatistics. The results also revealed that five paragraphs received a high degree of attitude, seventeen paragraphs received a medium degree, while none of the paragraphs classified in the low attitude degree. Based on the results, the study recommended that statistical activities should be linked with students' life and specializations, focusing on practical skills rather than theoretical ones, conducting a periodic and continuous evaluation for the university students to identify their attitudes towards statistics and strengthening the role of academic guidance and counseling to enhance students' positive attitudes towards their statistical capabilities.
\end{abstract}

Keywords: Attitudes Towards Statistics, Biostatistics, Survey Qualitative Research.

\section{Introduction}

Statistics is a noun for the verb (reckon) which means: to count (Al-Razi, 1967). In Arabic language, statistics is basically a science that involves data collection, data interpretation and finally, data validation until the appropriate decision is made (Abu Zeid, 2003). Also, it is the science of gathering, reviewing, analyzing, interpreting and drawing conclusions from data (Abu Saleh \& Awad, 2004).

The concept of statistics as counting began during the era of the Pharaohs especially during the reign of Ramses II (Abd Rabbo, 2001), Statistics in the modern sense of the word began evolving in the 18th century and developed until it reached its stable and well-known 
foundations, principles and theories. Statistics has grown and involved the development of methods and tests, mathematical and standard techniques and experimental objectives (Abu Zeid, 2003).

Statistics has become an effective tool, procedure and a useful means in various sciences and not an end in itself; it is widely used in planning, evaluating, and managing the institutions of countries and their various departments, through concerning in collecting, organizing, analyzing, interpreting, and presenting data. (Hamdawi, 2018).

The role of statistics, with its recognizably outstanding position amidst humanities in general and in scientific research in particular is undeniable during studying any type of phenomenon. Hence, Statistics cannot be dispensed with in any scientific research which is based on adherence to core value such as honesty, consistency, scientific accuracy and academic legitimacy (Abu Zaid, 2003).

The researchers believe that statistics began since ancient times, it is common and mutual element of all sciences and interdependent with arguably all of them. Statistics contributed to an enormous variety of research that make benefit of statistics in varying proportions. Therefore and due to development and progress in all fields, statistics has developed to several branches such as: biostatistics, economic statistics, political statistics, agricultural statistics, mechanical statistics and linguistic statistics.

Biostatistics is a compound term of biology and statistics, sometimes referred to as biostatistics or biometrics. It is the application of statistics to a wide range of topics especially those related to human biology, health, and medicine, through collecting, analyzing and interpreting biological data, therefore, biostatistics is concerned with finding the causes of diseases, and extends to predicting diseases and symptoms before they occur (Abdo, 2017 ).

The attitude towards statistics is related to the concept of statistical awareness or statistical culture, which is the degree of individuals' awareness of the importance of statistical information, and its impact on the research quality and planning, so that the higher the degree of individuals' awareness of statistical information, the higher their cultural and statistical awareness which certainly helps in dealing with accurate data collection. In fact, the impact of statistical awareness on the success of statistical work is great, but the biggest influence results from community awareness and not from awareness of individuals. Developed societies that enjoy a great statistical awareness and culture are characterized by the success of their statistical projects. However, individuals who do not have this awareness report negative attitudes towards statistics (Mofarraj, 2020).

Awareness has formed the cornerstone of attitudes in any field as long as the human being is its center; the depth of awareness is the most important step towards identifying the problem and its aspects. Cultural and statistical awareness are strongly associated with knowing the importance of statistics in all life aspects and the consequent behavior towards collecting, processing, publishing and dealing with data, and encouraging such behavior cannot be achieved without knowledge; Accordingly statistical awareness might be defined as positive behavior based on awareness and knowledge of the importance of statistics (Al-Samarrai, 2015).

The researchers believe that culture and statistical awareness must be raised among individuals and society as a whole, since they contribute to forming positive attitudes towards statistical work areas. 
The idea of the current study has been formed based on the following: the importance of measuring students' attitudes towards statistics in order to further develop these attitudes through building strategic programs, and students' low academic achievement in statistics courses due to the negative attitudes they have, which could be attributed to the lack of educational activities they are exposed to and the large number of statistical expressions the teacher use. To the best of the researchers' knowledge, there is a dearth of search conducted on students' attitudes towards biostatistics which seems to be gap areas.

\section{Problem of the study}

Through their experience in the field of teaching statistics, the researchers noticed the consistently poor performance exhibited by students in biostatistics tests and the small significantly success rates, lack of interest and the existence of negative attitudes, which may be attributed to the large number of terms, concepts, and theories used in biostatistics. Therefore, developing students' attitudes towards biostatistics demands the use of various tasks and skills, which initially require revealing the degree of their attitudes towards biostatistics.

Although the studies that measured the attitudes towards statistics among students were few at the global and Arab levels, the use of a scale to measure students' attitude towards statistics is essential in order to build appropriate statistical tasks and evaluate their statistical thinking, therefore, an attitude rating scale with three response categories (low, medium, high) was developed to measure students' attitudes toward biostatistics.

A plethora of research ( e.g., Abu Fouda, 2020; Al-Alfi, 2018; Al-Feki, 2018; Murabaha et al., 2016; Mezrag, 2015; Brahmi and Boujalal, 2015; Mubarak, 2015; Ahmed, 2012; Al-Habahbeh, et al., 2011; Salim and Rayan, 2009; Al Smadi, 2008) conducted on the attitudes towards statistics, the aim of this study is to extend previous research and seek for university students' attitudes towards biostatistics course and reveal its relationship with other variables.

\section{Questions of the Study}

1- What is the degree of students' attitudes at Al-Ghad International College for Applied Medical Sciences towards biostatistics on each paragraph of the attitude scale?

2- What is the degree of each student's attitude at Al-Ghad International College for Applied Medical Sciences towards biostatistics on all paragraphs?

\section{Objectives of the Study}

1- Revealing the degree of students' attitudes at Al-Ghad International College for Applied Medical Sciences towards biostatistics on each paragraph of the attitude scale.

2- Revealing the degree of each student's attitude at Al-Ghad International College for Applied Medical Sciences towards biostatistics on all paragraphs.

\section{Significance of the Study}

After reviewing the studies about biostatistics, it was valued as extremely important in the teaching learning process. The findings of the current study are expected to contribute to educational literature by providing potentially significant information and new insights on students' attitudes at Al-Ghad International College for Applied Medical Sciences towards biostatistics which is considered one of the main basic necessities in learning statistics. The 
study is also a response to the recommendations of other research called for exploring university students' attitudes towards statistics and could be the first step in conducting more studies related to the degree of university students' attitudes towards statistics and biostatistics.

Based on the findings and recommendations, the study is hoped to assist decision-makers and curricula designers in the educational field in Saudi universities to benefit from the results and provide various activities in the curricula and textbooks to develop students' attitudes towards statistics. Furthermore, the study scale can be valid for measuring university students' attitudes towards statistics in different environments and backgrounds.

\section{Definition of Term}

Students' Attitudes towards Biostatistics: It is student's feeling about biostatistics topics which contributes to determining his independent choice in terms of acceptance or rejection. In this study, it is measured by the score and degree obtained on the scale of attitudes towards biostatistics. Mean scores of students' responses were valued against the following criteria: (1.00 - 2.33 as low; 2.34 - 3.67 as intermediate; 3.68 - 5.00 as high). The percentage was calculated according to the following equation: The highest value - The lowest value/category number. In the present research, the highest value was 5; the lowest value was 1 ; and the category numbers were 3 . Thus, the appropriate class intervals were calculated as follows: $5-1 / 3=1.33$

\section{Literature Review}

Through the researchers' review of previous literature, they noticed the relative dearth of Arab studies which addressed students' attitudes towards statistics in particular, and its relationship to the development and evaluation of statistical skills, whereas the majority of previous studies concentrated mainly on the attitudes towards Statistics and statistical anxiety.

A rock solid piece of evidence can be traced in finding out students' attitudes towards statistics, empirical research has yielded effective results. Abu Fouda (2020) aimed to find out the relationship between the statistical anxiety variable and achievement in the principles of statistics course. Mubarak and Batayneh (2019) identified the predictive ability of negative thinking with statistical anxiety among graduate students at the university, Zadam and Zreiq (2019) diagnosed the causes of Statistical anxiety among students who are completing their graduation notes, Al-Alfi (2018) identified students' attitudes towards statistics and research implementation, Al-Fiqi (2018) revealed the effectiveness of teaching a statistics course in modifying the attitude towards statistics among graduate students, Kamal and Shatat (2017) determined the effectiveness of a teaching model to reduce mathematics anxiety, Abu Aish (2017) explored the relationship between statistical anxiety and motivation for learning and statistical achievement, Murabaha,et al (2016) measured students' attitudes towards learning biostatistics and their relationship to some variables, Mezraq (2015) clarified the relationship between learning skills, remembrance and attitude towards statistics among MA students, Brahmi and Boujalal (2015) clarified the relationship between learning and memorization skills and the attitude toward statistics using the descriptive correlative approach, Mubarak (2015) monitored the impact of using the statistical program (SPSS) and attitudes towards statistics, Al-Saleh (2014) examined differences in statistical anxiety with age and gender variables for social sciences students, Ahmed ( 2012) investigated the effect of using active learning strategies on the attitude towards statistics and academic self- 
motivation, Al-Hababah, et, al (2011) identified the attitudes of MA students towards statistics, Salim and Rayan (2009) identified the attitudes of university students towards statistics and their relationship to academic achievement.

The current study benefited from previous studies in presenting and enriching the theoretical literature, developing the study instrument, determining the methodology used, discussing the results and identifying the problem and objectives of the study. Therefore, this study extends previous studies (e.g., Abu Fouda, 2020; Al-Alfi, 2018; Al-Fiqi; Al-Murabaha and others, 2016; Mezrag, 2015; Brahmi and Boujalal, 2015; Mubarak, 2015; Ahmed, 2102; AlHabahbeh et al., 2011; Salim and Rayan, 2009; Al-Smadi, 2008) which called for seeking the attitudes of university students towards biostatistics course and its relationship with other variables. The current study agreed with previous in investigating students' attitudes and concerns about statistics.

In light of the forgoing and upon reviewing theoretical literature, little research has been conducted on students' attitudes towards statistics in general and biostatistics in particular; the few studies that dealt with anxiety and fear were in mathematics only. The researcher could not locate any research that focuses on students' attitudes towards biostatistics, thus, the study is expected to add to the existing body of related research. Also, previous studies used measures of attitude applied in mathematics while the current study particularly developed a scale for the measurement of attitude towards biostatistics for university students.

\section{Study Methodology}

Since the study is a qualitative survey for one group, and based on its problem, objectives and questions, the appropriate approach used is the descriptive-analytical. Obeidat, et, al (2007) mentioned that the descriptive approach is the process of parsing data to better understand the changes that have occurred and intends to examine a real life phenomenon to understand how people act in real situations, expressing them qualitatively or quantitatively, and identifying the interrelationships involved in their occurrence and analyze the variables affecting their development.

The study included one variable which is the degree of students' attitudes towards biostatistics, classified into three categories: (high - medium - low).

\section{Study Sample and Population}

The study population consisted of male and female students in Al-Ghad International College for Applied Medical Sciences ( $N=304$ ) enrolled in Biostatistics (BIOS 101) for the first time the first level in the first semester of the academic year 2018-2019, distributed over eight branches in the following regions of the Kingdom of Saudi Arabia: Riyadh, Jeddah, Dammam, Medina, Tabuk, Qassim, Najran, and Abha. The study sample was selected by cluster random sampling method $(n=205)$ and constituted $(67.43 \%)$ of the study population which much larger than the average sample size determined by Stephen Thompson's equation (Thompson, 2002).

\section{Study Instrument}

Based on an extensive review of the literature (Al-Smadi,2008; Abu Fouda, 2020; Mubarak and Batayneh, 2019; Zadam and Zreiq, 2019; Al-Alfi, 2018; Al-Feki, 2018; Kamal and Shatat, 2017; Abu Aish, 2017; Murabaha et., al, 2016; Mezrag, 2015; Brahmi and Boujalal, 2015; Mubarak, 2015; Al-Saleh, 2014; Ahmed, 2012; Al-Hababah et al. ,2011; Salim and Rayan, 
DEVELOPMENT

Vol. 11, No. 1, 2022, E-ISSN: 2226-6348 @ 2022 HRMARS

2009) and to achieve the objectives, the scale for the measurement of students' attitude towards biostatistics was developed and consisted of (23) paragraphs spread over five main factors. The students' responses were analyzed in terms of the five-point Likert scale; (strongly agree, agree, undecided, disagree, strongly disagree with the numerical values of (five, four, three, two and one) respectively.

\section{Validity and Reliability of the Study Instrument}

In order to examine the apparent validity of the instrument, a panel of educational experts reviewed the instrument. The team was asked to validate the content of the instruments concerning its paragraphs, appropriateness to the purposes of the current study, the language clarity, and how well they represent students' attitudes towards biostatistics. The teams' comments and recommendations were studied carefully and taken into account in amending the final version of the instrument.

To check the construct validity of the instrument, the Spearman RHO Correlation coefficient was calculated, the instrument was applied to a pilot group of 10 students selected randomly and left out later from the study sample. The test reliability coefficient was estimated using the internal consistency method by calculating the correlation coefficients between each factor and the total sum of factors. The correlation coefficients between each paragraph and the factor to which it belongs were also calculated as shown in Table 1 below:

Table 1: Correlation coefficients between the scores of each factor and the total score of the scale.

\begin{tabular}{lccc}
\hline$\#$ & Factors & $\begin{array}{c}\text { Paragraphs } \\
\text { NO }\end{array}$ & $\begin{array}{c}\text { Spearman's rho } \\
\text { Correlation coefficient }\end{array}$ \\
\hline 1 & Performance & 8 & $.756^{* * 0}$ \\
\hline 2 & Future need & 4 & $.630^{* * 0}$ \\
\hline 3 & Pleasure & 3 & $.714^{* * 0}$ \\
\hline 4 & Influence of the faculty member & 4 & $.708^{* * 0}$ \\
\hline 5 & Perceived importance & 4 & $.682^{* * 0}$ \\
\hline
\end{tabular}

Statistically significant at $(\alpha \leq 0.05)$

Statistically significant at $(\alpha \leq 0.01)$

Table 1 shows that all correlation coefficients of the five factors with the total score of the scale are statistically significant at $(\alpha \leq 0.01)$ and ranged between $(0.630-0.756)$, and since all correlation values are positive, the factors contribute positively to the overall degree of the scale, and in general, it was found that the factors have a high degree of internal consistency and able to measure the phenomenon under study with a high degree of stability.

Using Spearman's RHO correlation equation, the experimental validity coefficient was also tested between the scores of the study sample on each paragraph of the scale and the total score of the factor to which the paragraph belongs, as shown it Table 2 below: 
Table 2: Correlation coefficients between the score of each paragraph and the total score of the factor to which it belongs.

\begin{tabular}{|c|c|c|c|c|}
\hline Factors & $\begin{array}{c}\text { Paragraph } \\
\text { NO }\end{array}$ & $\begin{array}{l}\text { correlation } \\
\text { coefficient }\end{array}$ & $\begin{array}{c}\text { Paragraph } \\
\text { NO }\end{array}$ & $\begin{array}{l}\text { correlation } \\
\text { coefficient }\end{array}$ \\
\hline \multirow{4}{*}{ Performance } & 2 & $.557 * * 0$ & 13 & $.320 * 0$ \\
\hline & 3 & $.677 * * 0$ & 14 & $.597 * * 0$ \\
\hline & 9 & $.497 * * 0$ & 15 & $.317 * 0$ \\
\hline & 10 & $.603 * * 0$ & 19 & $.515 * * 0$ \\
\hline \multirow{2}{*}{ Pleasure } & 11 & $0.329 *$ & 16 & $0.639 * *$ \\
\hline & 12 & $0.622 * *$ & 17 & $0.692 * *$ \\
\hline \multirow[t]{2}{*}{ Future need } & 5 & $0.749 * *$ & 23 & $.869 * *$ \\
\hline & 7 & $0.625 * *$ & & \\
\hline \multirow{2}{*}{$\begin{array}{l}\text { Influence of the faculty } \\
\text { member }\end{array}$} & 18 & $0.883 * *$ & 21 & $0.874 * *$ \\
\hline & 20 & $0.952 * *$ & 22 & $0.945 * *$ \\
\hline \multirow{2}{*}{ Perceived importance } & 1 & $0.475 * *$ & 6 & $0.730 * *$ \\
\hline & 4 & $0.789 * *$ & 8 & $0.568 * *$ \\
\hline
\end{tabular}

Statistically significant at $(\alpha \leq 0.05)$

Statistically significant at $(\alpha \leq 0.01)$

Table 2 shows that Spearman's correlation coefficients for the first factor (performance) ranged between ( 0.317 to 0.677 ), the second factor (future need) ranged between ( 0.329 to 0.692), the third factor (pleasure ) ranged between (0.625 to 0.869), the fourth factor (influence of the faculty member) ranged between (0.874 to 0.952$)$ and the fifth factor (perceived importance) ranged between ( 0.475 to 0.789 ), they are all statistically significant at $(\alpha \leq 0.05)$ or $(\alpha \leq 0.01)$. Since all correlation values are positive, the paragraphs contribute positively to the total degree of the factor to which they belong, which indicates that the scale is characterized by a high degree of validity.

\section{Reliability of the Study Instrument}

A Cronbach Alpha reliability analysis was conducted on the same pilot of study in addition to a split-half coefficient as shown it Table 3 below: 
Table 3: A Cronbach Alpha reliability and a split-half coefficient analysis

\begin{tabular}{cccc}
\hline Factor & $\begin{array}{c}\text { Paragraphs } \\
\text { NO }\end{array}$ & $\begin{array}{c}\text { Reliability } \\
\text { Coefficient - } \\
\text { Cronbach's } \\
\text { Alpha }\end{array}$ & $\begin{array}{c}\text { Reliability } \\
\text { split-half } \\
\text { coefficient }\end{array}$ \\
\hline Performance & 8 & 0.588 & 0.590 \\
\hline Future need & 4 & 0.403 & 0.668 \\
\hline Pleasure & 3 & 0.618 & 0.780 \\
\hline Influence of the faculty member & 4 & 0.932 & 0.938 \\
\hline Perceived importance & 4 & 0.539 & 0.553 \\
\hline $\begin{array}{c}\text { The reliability of the scale as a } \\
\text { whole }\end{array}$ & 23 & 0.855 & 0.766 \\
\hline
\end{tabular}

Table 3 shows that the values of the reliability coefficients using the Alpha Cronbach ranged between (0.403-0.932), with a total reliability of (0.855). Also, the values of the reliability coefficients using the split-half method ranged between (0.553-0.938) with a total reliability of (0.766), which all are considered high and suitable to conduct the study.

\section{Results and Discussion}

The first research question sought the degree of students' attitudes at Al-Ghad International College for Applied Medical Sciences towards biostatistics on each paragraph of the attitude scale. The degree of students' attitude toward biostatistics was calculated on each paragraph of the attitude scale as shown in Table 4 below:

Table 4: Means, standard deviations, percentages, and ranks of students' degrees on the paragraphs of the attitude scale.

\begin{tabular}{|c|c|c|c|c|c|c|}
\hline$\#$ & Paragraphs & Mean & SD & $\%$ & Rank & $\begin{array}{l}\text { Degree of } \\
\text { Attitude }\end{array}$ \\
\hline 18 & $\begin{array}{l}\text { The friendly way the teacher } \\
\text { answers the questions makes } \\
\text { me love biostatistics }\end{array}$ & 3.78 & 1.013 & 75.60 & 1 & High \\
\hline 20 & $\begin{array}{c}\text { The explanations provided by } \\
\text { the teacher made } \\
\text { biostatistics interesting }\end{array}$ & 3.76 & .994 & 75.20 & 2 & High \\
\hline 22 & $\begin{array}{c}\text { The teacher played a big role } \\
\text { in my love for biostatistics }\end{array}$ & 3.76 & .994 & 75.20 & 3 & High \\
\hline 19 & $\begin{array}{l}\text { When I don't understand a } \\
\text { part of biostatistics, I don't } \\
\text { hesitate to ask the teacher } \\
\text { about it }\end{array}$ & 3.73 & 1.025 & 74.60 & 4 & High \\
\hline 1 & $\begin{array}{c}\text { Biostatistics is an important } \\
\text { science with great applied } \\
\text { value }\end{array}$ & 3.71 & .981 & 74.20 & 5 & High \\
\hline 16 & $\begin{array}{l}\text { Statistics will improve my } \\
\text { ability in scientific research }\end{array}$ & 3.59 & .948 & 71.80 & 6 & Medium \\
\hline
\end{tabular}




\begin{tabular}{|c|c|c|c|c|c|c|}
\hline 21 & $\begin{array}{l}\text { I love biostatistics because of } \\
\text { the way the teacher teaches }\end{array}$ & 3.56 & 1.097 & 71.20 & 7 & Medium \\
\hline 10 & $\begin{array}{l}\text { I am calm and unafraid when } \\
\text { I study biostatistics }\end{array}$ & 3.44 & 1.050 & 68.80 & 8 & Medium \\
\hline 14 & $\begin{array}{l}\text { Learning biostatistics is easy } \\
\text { for me }\end{array}$ & 3.44 & 1.001 & 68.80 & 9 & Medium \\
\hline 23 & In general I like biostatistics & 3.39 & 1.022 & 67.80 & 10 & Medium \\
\hline 6 & $\begin{array}{l}\text { Biostatistics is a theoretical } \\
\text { subject } \\
\text { so that it is of little practical } \\
\text { use in most professions }\end{array}$ & 3.29 & 1.230 & 65.80 & 11 & Medium \\
\hline 17 & $\begin{array}{l}\text { I will be more skilled in my } \\
\text { major if I master biostatistics }\end{array}$ & 3.29 & 1.188 & 65.80 & 12 & Medium \\
\hline 13 & $\begin{array}{c}\text { I don't get frustrated when I } \\
\text { don't solve biostatistics } \\
\text { problems }\end{array}$ & 3.22 & .962 & 64.40 & 13 & Medium \\
\hline 5 & $\begin{array}{l}\text { Biostatistics is my exciting } \\
\text { and favorite subject }\end{array}$ & 3.12 & .927 & 62.40 & 14 & Medium \\
\hline 4 & $\begin{array}{l}\text { Biostatistics does not interest } \\
\text { me at all }\end{array}$ & 3.07 & 1.212 & 61.40 & 15 & Medium \\
\hline 15 & $\begin{array}{c}\text { Biostatistics makes me } \\
\text { anxious }\end{array}$ & 3.05 & 1.048 & 61.00 & 16 & Medium \\
\hline 3 & $\begin{array}{l}\text { I do not do well in } \\
\text { biostatistics }\end{array}$ & 3.02 & 1.129 & 60.40 & 17 & Medium \\
\hline 9 & $\begin{array}{l}\text { I feel like I can't think when I } \\
\text { face a statistic issue }\end{array}$ & 2.98 & 1.012 & 59.60 & 18 & Medium \\
\hline 7 & $\begin{array}{l}\text { I enjoy talking to others } \\
\text { about biostatistics }\end{array}$ & 2.90 & .860 & 58.00 & 19 & Medium \\
\hline 2 & $\begin{array}{l}\text { If biostatistics was optional } \\
\text { course, you wouldn't have } \\
\text { studied it }\end{array}$ & 2.85 & 1.152 & 57.00 & 20 & Medium \\
\hline 8 & $\begin{array}{l}\text { I consider that biostatistics is } \\
\text { important for those who } \\
\text { want to be a researcher only } \\
\text { and not for anyone else }\end{array}$ & 2.71 & 1.146 & 54.20 & 21 & Medium \\
\hline 11 & $\begin{array}{l}\text { I expect to make little use of } \\
\text { statistics in my specialization } \\
\text { and future profession }\end{array}$ & 2.51 & 1.075 & 50.20 & 22 & Medium \\
\hline 12 & $\begin{array}{c}\text { Other subjects are more } \\
\text { important to my profession } \\
\text { than biostatistics }\end{array}$ & 2.51 & 1.003 & 50.20 & 23 & Medium \\
\hline & Total & 3.25 & 0.513 & 64.94 & --- & Medium \\
\hline
\end{tabular}


Table 4 shows that $64.94 \%$ of the study sample has a significantly medium level of attitude towards biostatistics; with a mean of 3.25 .

The high level of attitude towards biostatistics appeared on five paragraphs of the scale numbered:18-20-22-19-1 in descending order with mean scores of 3.71 to 3.78 , and a percentage of $74.20 \%$ to $75.60 \%$, the level of attitude was medium on the remaining seventeen paragraphs (16-21-10-14-23-6-17-13-5-4- 15-3-9-7-2-8-11-12) in descending order, with a mean of 2.51 to 3.59 , and a percentage of $50.20 \%$ to $71.80 \%$, while none of the paragraphs were classified at a low attitude level.

The top five paragraphs with a high degree of attitude were $(18,20,22-19-1)$ arranged in descending order as follows:

1) The friendly way the teacher answers the questions makes me love biostatistics.

2) The explanations provided by the teacher made biostatistics interesting

3) The teacher played a big role in my love for biostatistics

4) When I don't understand a part of biostatistics, I don't hesitate to ask the teacher about it

5) Biostatistics is an important science with great applied value.

While the least five paragraphs with a medium degree of attitude were $(12,11,8-2-7)$

arranged in descending order as follows:

1) Other subjects are more important to my profession than biostatistics

2) I expect to make little use of statistics in my major and future profession

3) I consider that biostatistics is important for those who want to be a researcher only and not for anyone else

4) If biostatistics was optional course, you would not have studied it

5) I enjoy talking to others about biostatistics.

The second research question sought the attitudes of each student on all scale paragraphs. According to the classification reported in (AI-Smadi, 2008) the attitude of each student towards biostatistics was investigated, each student was classified separately according to the standard: (mean $\pm 1 \times$ SD). The mean and total standard deviation of the study sample members on the scale of attitude towards biostatistics reached: (mean $=74.68, S D=11.80$ ). Accordingly, the type and degree of attitude towards biostatistics were identified as shown in Table 5 below. 
Table 5: Distribution of the study sample members separately according to the standard: (mean $\pm 1 \times$ SD) to identify type and degree of attitude towards biostatistics.

\begin{tabular}{|c|c|c|c|c|c|c|}
\hline $\begin{array}{l}\text { Degree } \\
\text { of } \\
\text { attitude }\end{array}$ & $\begin{array}{l}\text { Type of } \\
\text { attitude }\end{array}$ & $\begin{array}{c}\text { Standard } \\
\text { Classification } \\
\text { mean } \pm 1 \times \text { SD }\end{array}$ & $\begin{array}{c}\text { Interval } \\
\text { mean = } \\
74.68 \\
S D= \\
11.80\end{array}$ & No & $\begin{array}{c}\text { Percentage } \\
\%\end{array}$ & $\begin{array}{c}\text { Total } \\
\text { percentage } \\
\%\end{array}$ \\
\hline Low & negative & $\begin{array}{c}\text { Less Than (Mean } \\
\text { - Standard } \\
\text { Deviation( }\end{array}$ & $\begin{array}{c}\text { Less } \\
\text { than } \\
62.88\end{array}$ & 55 & $\% 26.8$ & $\% 26.8$ \\
\hline \multirow{2}{*}{ medium } & $\begin{array}{c}\text { medium } \\
\text { towards } \\
\text { negativity }\end{array}$ & $\begin{array}{c}\text { between (mean - } \\
\text { standard } \\
\text { deviation( }\end{array}$ & $\begin{array}{c}]-62.88 \\
74.68[\end{array}$ & 75 & \%36.6 & \multirow{2}{*}{$\% 51.2$} \\
\hline & $\begin{array}{l}\text { medium } \\
\text { towards } \\
\text { positivity }\end{array}$ & $\begin{array}{c}\text { between (mean } \\
+ \text { standard } \\
\text { deviation( }\end{array}$ & $\begin{array}{l}]-74.68 \\
86.48[\end{array}$ & 30 & \%14.6 & \\
\hline High & Positive & $\begin{array}{l}\text { More than } \\
\text { (mean }+ \\
\text { standard } \\
\text { deviation( }\end{array}$ & $\begin{array}{l}\text { More } \\
\text { than } \\
86.48\end{array}$ & 45 & $\% 22.0$ & $\% 22.0$ \\
\hline
\end{tabular}

- $\quad$ Table 5 suggests that (22\%), (51.2\%), (26.8\%) of students had a low, medium and high level of attitude toward biostatistics respectively. in which (\%14.6) marked by a prejudiced, negative attitude to the medium. and (36.6\%) marked by a positive attitude to the medium. In general the medium level was prevailing.

- There are generally statistically significant differences among the study sample members according to the level of their attitudes towards biostatistics.

The result goes in line with (Murabaha et al., 2016; Mills, 2004; Mvududu, 2003; Piotrowski et al., 2002) who attributed the lack of high positive attitudes towards biostatistics to the difficulties that students face in understanding statistical concepts. Statistics courses are viewed by most medical college students and those enrolled in introductory statistics courses as an obstacle standing in the way of attaining their desired degree and consequently causes more tension and fear throughout the semester, which in turn, contribute to developing negative attitudes about the domain of statistics.

The researchers also believe that the medium level of attitude towards biostatistics is logical, since biostatistics is one of the secondary courses and given to all disciplines in the preparatory year in the college, and despite its importance, it is not of primary students' interest, therefore, college management is making intensive efforts to improve students' statistical performance which is needed in both scientific and medical research to further reflect positively on their professional and future performance. The result seems to be consistent with (Marabhah et al., 2016), which indicated that students at the faculty of medicine have expressed varying interest towards biostatistics course as a compulsory subject during their first academic year. The findings also agreed with previous studies such as (Marabhah et al., 2016), which showed that the degree of attitude towards biostatistics 
was medium among Arab Gulf University students, also the study of (Zhang et al., 2012) which showed that most of students' attitudes towards statistics at the University of Medical Sciences in China were medium. Besides Mubarak \& Batayneh (2019); Abd (2017); the study of Al-Katani and Al-Ajili (2012), the study of Al-Hababah et al (2011); Ryan \& Salim (2009); Ryan's (2008); Al-Smadi's (2008); which expressed medium attitudes towards learning statistics.

With regard to the negative attitudes towards statistics, the researchers believe that the reason behind that might not only be the poor statistical skills or insufficient knowledge of statistics, but also students' negative experiences and perceptions of statistical courses. The negative connotations of anxiety on performance have been widely studied in relation to statistics, it is generally accepted that negative attitudes increase the level of anxiety and produce lower achievement, Additionally, students showing a combination of negative attitudes towards statistics, such as, low motivation, low enjoyment and low perceived usefulness, Moreover, students have differences statistical background, some of them do not have enough knowledge and lack sufficient self-confidence in dealing with numbers, which resulted in negative attitudes towards statistics courses. Also, students become anxious when they attend the first statistical course and, when possible, attempt to delay taking the required statistics courses until just before the end of their program. The result seems to be in line with several studies (e.g., Slootmaeckers \& Kerremans, 2014; Williams, 2010; Galli et al., 2008; Finch \& Jameson, 2007; OnWuegbuzie \& Wilson, 2003; Mubarak \& Batanah, 2019; Zdam and Zurek, 2019; Al-Alfi, 2018; Fodeh, 2018; Abd, 2017; abu Aish, 2017; ;Al- Titi et al., 2015; Brahmi and Buglal, 2015; Mezraq, 2015; Ahmed, 2012; Smadi, 2008) which have identified negative attitudes towards statistics.

The researchers also believe that the medium level of students' attitude towards biostatistics could be attributed to their cognitive or intellectual component towards statistics which is the key part in the formation of an attitude in any individual. Cognitive component involves the sum total of person's belief, knowledge, culture, education, experiences and points of view about an attitude object that reached through memorization or direct practice (Qarwani, 2017). Accordingly, the students' cognitive component gave them a medium level of attitude towards biostatistics.

Paragraphs related to the teacher and the need for his help received the highest scores and high level of attitudes. This result agreed with (Fouda, 2020) and indicates the importance of the teacher of statistics and the huge burden over his shoulders, since he forms the positive attitudes towards statistics. The researchers believe that the positive attitudes are inspired by the teacher of biostatistics not the subject itself. The negative attitudes towards biostatistics is state anxiety which refers to a transitory emotional response involving tension and apprehensive thoughts and goes away once the threat passes, not trait anxiety which is the fact of being prone to anxiousness.

It is also believed that the emotional component formed the positive attitudes towards the teacher of biostatistics, which refers to the feelings of love and hate that the individual carries towards a particular subject; and the intensity of these feelings fluctuates according to the individual's acceptance or rejection of the subject (Al-Smadi, 2008). 
The lowest scores for paragraphs with a medium level of attitude correlate with the perceived usefulness of statistics, its content, value, importance and the enjoyment of studying it. The result may be attributed to the fact that biostatistics is given to Al-Ghad College students in the first level of their studies, and most of them do not realize the benefit of studying biostatistics in understanding, classifying, analyzing and interpreting various statistical data in their medical specialties, in addition to the benefit of implementing their medical graduation projects, and further in completing their higher education studies.

The overriding goal of all teaching ought to be to stimulate learning that lasts; the researchers believe that something had gone very badly wrong with teaching statistics in previous academic stages which might stands behind the reason why the students did not realize its usefulness and importance. The result is consistent with the study of (Abd, 2017) which stressed that no focus was given to linking statistics to reality and practical life. Rather, it is likely that statistics was taught to students in the form of symbols, laws and relationships isolated from reality in which students use. Accordingly, students' negative attitudes towards statistics could turn into trait anxiety, which is a part of the personality dimension of neuroticism and report negative emotions such as fears, worries, and anxiety across many situations but away from the one that caused the anxiety. The result goes in line with (Fouda, 2020) which suggests that students' perceptions of their past school stages, influenced their negative attitude traits towards statistics, and despite moving to university, the trait of negative attitudes is still rooted.

\section{Recommendations}

Based on the results of the current study, the researchers recommend the following:

- The necessity of making every effort to review the teaching and evaluation processes of biostatistics course and the learning environment within the Al-Ghad International College for Applied Medical Sciences due to students' poor attitudes towards biostatistics.

- Linking statistical activities to the reality of students' lives and specializations, and focusing on practical aspects rather than theoretical ones.

- The biostatistics faculty should take into consideration the statistical and mathematical backgrounds of university students while presenting statistical concepts.

- Strengthening the role of academic counseling in universities in a way that enhances students' positive attitudes towards their statistical abilities.

- Paying attention to students' attitudes towards biostatistics, and trying to build positive attitudes through diversifying activities related to teaching and evaluating the medical statistical aspect.

- Conducting a periodic and continuous evaluation to identify the university students' attitudes towards statistics.

- Conducting further research on MA and PHD students in other colleges and universities.

- Developing the scale prepared in this study by applying it to students from different backgrounds and environments to verify its validity, reliability and applicability to university students. 
DEVELOPMENT

Vol. 11 , No. 1, 2022, E-ISSN: 2226-6348 @ 2022 HRMARS

\section{References}

Abd Rabbo, I. (2001). Principles of Statistics, Alexandria, Egypt: Al-Rasaa Technical Library and Press.

Abd, Khaled, A. (2017). Attitude towards statistics and its relationship to the personality types $\{A B\}$ among graduate students, Uruk journal, 10, (1).

Abdo, S. (2017). Principles of Biostatistics - Applications in the Arab Environment, Noor Publishing and Distribution House, Sharjah: United Arab Emirates.

Abu Aish, B. (2017). Statistical anxiety and its relationship to motivation for learning and academic achievement among high diploma students at the Faculty of Education at Taif University, Journal of Psychological Counseling, Ain Shams University: Egypt, 49, 53-95.

Abu Fouda, B. (2020). Statistical anxiety and the attitude towards it in predicting the students' achievement in the Middle East University in Jordan in Principles of Statistics course, An-Najah University Journal for Research - Human Sciences, Volume 34 (2), 261-282.

Abu Saleh, M., \& Awad, A. (2004). Introduction to Statistics 'Principles and Analysis using SPSS' (1st Edition). Amman, Jordan: Dar Al Masirah for publishing, distribution and printing.

Abu Zaid, A. (2003). Statistics in Behavioral Sciences 'Statistical Description 1', Alexandria, Egypt: University Knowledge House for Printing, Publishing and Distribution.

Ahmed, S. (2012). The effectiveness of using active learning strategies in teaching psychological and educational statistics on modifying the attitude towards studying statistics and developing academic self-motivation, The Arab Journal of Education - The Arab Organization for Education, Culture and Science, 32, (1), 98-143.

Al-Alfi, M. (2018). The attitude towards statistics and research implementation in the light of some variables among MA students, Journal of the Faculty of Education, Al-Azhar University - Egypt. 177, (1), p. 77-113.

Al-Habahbeh, A., Al-Kharabsheh, O., \& Al-Qamsh, M. (2011). Attitudes of MA students at Princess Alia University College / Al-Balqa Applied University towards statistics and its relationship to some variables, Journal of the Union of Arab Universities, 57, 443-462.

Al-Katani, A., \&Al-Ajili, M. (2012). Attitudes of the students of the Faculty of Physical Education at Al-Muthanna University towards statistics. The Eighteenth Regular Conference of the Colleges and Departments of Physical Education in Iraq, pp. 226-249.

Al-Mafraj, T. (2020). Statistical Awareness, Publications of the General Authority for Statistics in the Kingdom of Saudi Arabia - General Administration for Information and Statistical Awareness.

Al-Razi, M. (1967). Mokhtar Al-Sahah, Beirut, Lebanon: Arab Book House.

Al-Saleh, A. (2014). Statistical Anxiety, Age and Gender Differences in using the Standardized Correlation Coefficient Law, Journal of Social Affairs - Sociologists Association in Sharjah: United Arab Emirates. 31, (121), 11-32.

Al-Samarrai, F. (2015). Statistics and Medical Diagnostic Tests, Publications of the College of Medicine, University of Baghdad - Iraq.

Al-Smadi, A. (2008). Student Attitude Scale towards Statistics, Damascus University Journal, 2, (24).

Al-Titi, M., Jaradat, M., Ibdah, R. (2015). The level of worry indeed at graduate students in the collage of education, the direction of statistical material, and its relationship with some variables, Journal of Specific Education Research, Mansoura University - Faculty of Specific Education. 37 , p. 2-33.

Al-Feki, I., \& Abdessadeq, F. (2018). The Effectiveness of Teaching Statistics Course in Developing Self-regulation and Academic Achievement and to adjust the Attitude 
towards Statistics among Postgraduate Students, Journal of the Faculty of Education, Tanta University - Egypt. 70, (2), 1-54.

Brahmi, B., \& Boujelal, S. (2015). Learning and recall skills and their relationship to the attitude towards statistics among students of the Faculty of Economics, Commercial and Management Sciences, $A$ field study, at the University of $M^{\prime}$ 'sila, Algeria, 1, 41-66.

Finch, H., \& Jameson, M. M. (2007). Prior statistics coursework and student expectations of a graduate statistics class. In Festschrift in honor of Mir Masoom Ali, (pp.185-189). Muncie IN: Ball State University

Galli, S., Ciancaleoni, M., Chiesi, F., \& Primi, C. (2008). Who failed introductory statistics?, Paper presented at International Congress on Mathematical Education, Mexico. Retrieved on July 8, 2020 from http://tsg.icme11.org/document/get/526.

Hamdawi, J. (2018). Educational Statistics, 2nd Edition, Hamdaoui Cultural Publications, Tetouan: Maghreb.

Kamal, M., \& Shatat, R. (2017). The effectiveness of a teaching model based on self-organized learning in developing self-organization skills and the ability to solve statistical problems and reduce mathematics anxiety among preparatory year students at King Saud University, Educational Journal - Kuwait University - Kuwait, 70, (2), 1-54.

Mezrag, N. (2015). Learning and recall skills and their relationship to the attitude towards statistics for first-year MA students at the Department of Psychology and Education Sciences, a field MA study at the University of M'sila in Algeria, in Education Sciences, educational guidance and counseling.

Mills, D. (2004). Students' attitudes toward statistics: Implication for the future. College Student Journal, 38 (3), $349-361$.

Mofarraj, T. (2020). Statistical Awareness, Publications of the General Authority for Statistics in the Kingdom of Saudi Arabia - General Administration for Information and Statistical Awareness.

Mubarak, W., \& Batayneh, M. (2019). The predictive ability of negative thinking with statistical anxiety among graduate students, Education and Psychology Thesis, Specialized International Educational Journal - Jordan Psychological Association Jordan, . 8, (1), 76-85.

Mubarak, W. (2015). The effect of using SPSS in teaching statistics course on the achievement in statistics and the attitude towards statistics, Education and Psychology journal, Saudi Association for Educational and Psychological Sciences (Justin) - King Saud University: Saudi Arabia, 51, 73-90.

Marabhah, A., Jaradat, A., \& Nasser, F. (2016). Students' attitudes towards learning biostatistics and their relationship to some variables at the Arabian Gulf University, Journal of Educational Sciences, Vol. 24, Vol. 1, Vol. 1, 385-409.

Mvududu, N. (2003). A cross-cultural study of the connection between students' attitudes toward statistics and the use of constructivist strategies in the course. Journal of Statistics Education,11 (3).

Onwuegbuzie, A. J., \& Wilson, V. A. (2003). Statistics anxiety: nature, etiology, antecedents, effects, and treatments - a comprehensive review of the literature. Teaching in Higher Education, 8(2), 195-209.

Piotrowski, C., Bagui, S., \& Hemasinha, R. (2002). Development of a measure on statistics anxiety in graduate - level psychology students. Journal of Instructional Psychology, 29 (2), 97 - 100. 
Qarawani, M. (2017). Attitudes of Mathematics and Computer Students at Al-Quds Open University - Salfit Educational District - Towards the Use of E-Learning in Mathematics, Al-Quds Open University, The Palestinian Journal of Open Education, 3, (6).

Salim, K., \&Ryan, A. (2009). Attitudes of Al-Quds Open University students towards statistics and their relationship to academic achievement in light of some variables, The Palestinian Journal of Open Education and E-Learning, 2, (3).

Slootmaeckers, K., \& Kerremans, B. (2014). Too afraid to learn Attitudes towards statistics as barrier to learning statistics and to acquiring quantitative skills. Politics, 34, 191-200.

Thompson, S. K. (2002). On sampling and experiments, John Wiley \& Sons, Ltd.

Williams, A. S. (2010). Statistics anxiety and instructor immediacy. Journal of Educational Statistics, 18(2), 1-18.

Zadam, A., \& Zreiq, M. (2019). Statistical anxiety among students of the final departments a field study at the University of Abdelhamid Mehri Constantine 2-Institute of Science and Techniques of Physical and Sports Activities, Journal of Human Sciences, University of Mentouri Brothers Constantine - Algeria, p. 52, 469-479.

Zhang, Y., Shang, L., Wang, R., Li, C., Xu, Y., and Su, H. (2012). Attitudes toward statistics in medical postgraduates: measuring, evaluation and monitoring. BMCMedical Education, 23;12:117. doi: 10.1186/1472-6920-12-117. 